\title{
ETNOBOTÂNICA NA CULTURA DE BENZEDEIRAS E CURANDEIROS, MATO GROSSO, BRASIL
}

Margô De David ${ }^{1}$

Maria Corette Pasa

\section{INTRODUÇÃO}

A Etnobotânica é classicamente definida como a ciência que estuda o conhecimento e as conceituações desenvolvidas por qualquer sociedade a respeito do mundo vegetal, englobando tanto a maneira como o grupo social classifica as plantas quanto a finalidade que lhes dá (AMOROZO, 1996). Nessa percepção esta ciência passa a existir como sendo o campo interdisciplinar que compreende o estudo e a interpretação do conhecimento, significação cultural, manejo e usos tradicionais dos elementos da flora (CABALLERO, 1979).

Através da história da humanidade percebemos a vasta relação do homem com os recursos vegetais, principalmente na alimentação, construção, ornamentação, remédio e para a finalidade místico-religiosa. Apesar do desenvolvimento industrial atual, diversas comunidades mantêm uma forte dependência com a flora local.

Com base na evolução histórica do uso de plantas medicinais, a Organização Mundial de Saúde (OMS), em 1979, passou a reconhecer a fitoterapia como terapia alternativa de enfermidades humanas. $\mathrm{Na}$ década de 1990, estimou-se que a maioria da população mundial dependia essencialmente de plantas medicinais para os cuidados básicos de saúde. A utilização de plantas medicinais para tratamento, cura e prevenção de doenças é uma das mais antigas formas de prática medicinal da humanidade (LORENZI; MATOS, 2002).

No Brasil e em outros países tem ocorrido um avanço no interesse pelo conhecimento, utilização e comercialização de plantas

1 Profa. MSc. pelo PPG Bionorte. MT. margodedavid@hotmail.com

2 Profa. Drạ. do Departamento de Botânica e Ecologia/IB.UFMT. PPG em Ciências Florestais e Ambientais. UFMT. pasamc@brturbo.com.br; pasaufmt@gmail.com 
medicinais e produtos fitoterápicos, o que tem proporcionado uma grande expansão desse mercado.

Segundo Amorozo e Gely (1998), planta medicinal é toda espécie vegetal com valor curativo para determinada comunidade, ou seja, que possua uma propriedade real ou imaginária, aproveitada para um ou mais fins específicos de cura, que sejam empregadas na prevenção, no tratamento e na cura de distúrbios, disfunções ou doenças do homem e animais.

O conhecimento, o cultivo, a coleta e o uso de plantas medicinais são práticas rotineiras na medicina popular. Desta forma, as plantas medicinais estão entre os principais recursos manejados por diversas comunidades, sendo responsáveis pela inter-relação entre as pessoas e o ambiente natural (BEGOSSI et al., 2002; MIRANDA; HANAZAKI, 2008).

A medicina popular é de início, uma medicina tradicional e sua forma de transmissão é oral e gestual, através do 'ouvir-falar' e 'ver-fazer', que ocorre por meio da família ou dos vizinhos (PORTUGUAL, 1987). Entretanto, esta prática não é somente herdada, mas também acrescida e diversificada através dos relacionamentos existentes entre as pessoas de diferentes regiões do país, e os raizeiros são em parte responsáveis por tais práticas.

Benzedeiras, curandeiros, raizeiros e parteiras assumem um papel importante, indicando plantas para efeito de cura ou como amuletos protetores, estando esta forma de uso da flora presente na cultura popular. Portanto, atuam como mediadores entre o ser humano e o sagrado, devendo conservar o ritual de rezas, cruz e fórmulas (AMOROZO, 2004; MACIEL; GUARIM NETO, 2006). Assim, constituem um grupo de pessoas praticantes de determinados saberes. Ora atuam com os saberes de uma medicina prática e popular, ora com a religiosidade, geralmente unindo ambas.

Para Loyola (1983), são respeitados por suas comunidades e pacientes, onde fazem referência das enfermidades entendendo o adoecimento além do lado biológico, unindo elementos simbólicos passíveis de cura pela reza e por técnicas místicas utilizadas por especialistas da medicina e da religião. Contudo, não são reconhecidos por seus órgãos oficiais.

Segundo Pasa (2007), por meio da investigação científica de agentes biologicamente ativos, usados na medicina popular, a 
etnofarmacologia vem documentando e avaliando os agentes medicinais adotados em práticas tradicionais, bem como o desenvolvimento de medicamentos sem o uso da metodologia industrial. Para isso, as informações coletadas a respeito do uso de plantas são de fundamental importância, ressaltando que as plantas medicinais estão sendo revalorizadas porque, entre outras razões, é a forma mais acessível para a população local curar suas enfermidades. Neste sentido, ao realizar um levantamento etnobotânico, através da catalogação, sistematização e análise das principais espécies vegetais utilizadas por benzedeiras e curandeiros no sul do estado de Mato Grosso estaremos contribuindo significativamente para academia e sociedade em geral.

\section{PROTOCOLO EXPERIMENTAL}

O estudo foi desenvolvido no sul do estado de Mato Grosso (Figura 1), compreendendo os municípios de Rondonópolis, Dom Aquino, Itiquira, Jaciara, Juscimeira, Pedra Preta, São José do Povo e São Pedro da Cipa.

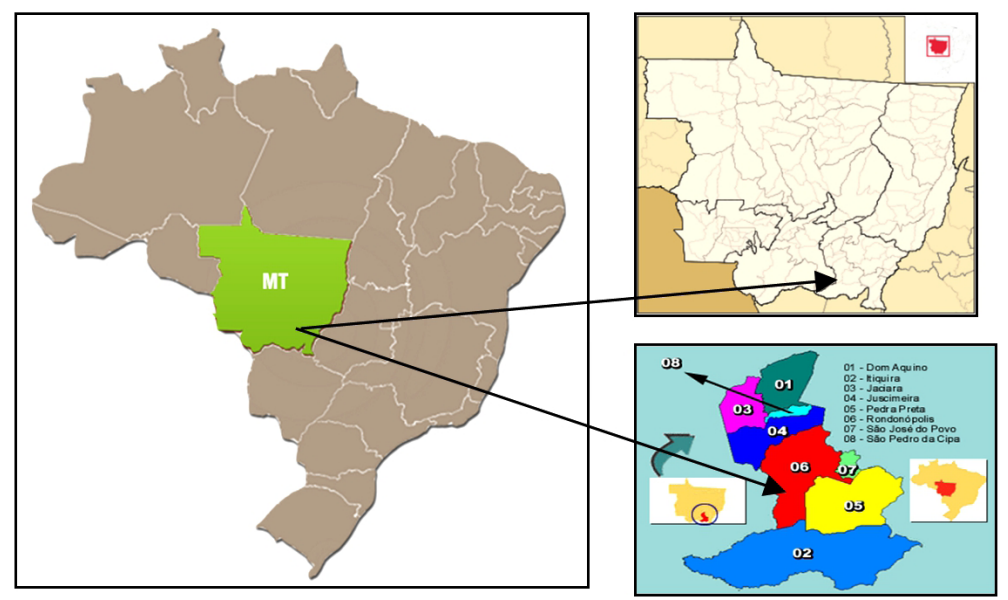

Figura 1 - Localização da área de estudo. Região sul do estado de Mato Grosso Fonte: Google maps. 2016.

A área abrange $23.854,413 \mathrm{~km}^{2}$, possui clima tropical úmido, com duas estações definidas, uma seca e outra chuvosa e a temperatura varia de $25^{\circ} \mathrm{C}$ a $38^{\circ} \mathrm{C}$ (CUTRIM; CAMPOS, 2010). $O$ 
bioma característico da região é o cerrado, porém com o passar das décadas vem sofrendo alterações ambientais e dando lugar, principalmente a agricultura e a pecuária.

Os dados foram coletados através da aplicação de entrevistas com benzedeiras e curandeiros entre o período de março a novembro de 2016. Primeiramente foi realizado um levantamento da região com a aplicação de um pré-teste para testar e selecionar as melhores técnicas a serem utilizadas.

O procedimento metodológico abordou Tratamento Qualitativo envolvendo as seguintes técnicas: Pré-teste, Observação Direta, Entrevistas dos tipos Semiestruturada e Aberta (MINAYO, 1994), Turnê Guiada e História de Vida, onde os informantes narram as experiências vividas (MEIHY, 1996). Essas técnicas serviram para obtenção dos dados referentes aos aspectos sociais, econômicos e culturais de benzedeiras e curandeiros, levantamento etnobotânico das plantas usadas, procedimentos de preparo e modos de uso.

Durante a coleta de dados foi utilizada máquina fotográfica digital para armazenar imagens que envolveram as entrevistas, o manejo com as plantas e outros símbolos utilizados, além de diário de campo com a finalidade de registrar as informações e acontecimentos pertinentes à pesquisa.

\section{RESULTADOS E DISCUSSÃO}

\section{Aspecto socioeconômico}

As entrevistas ocorreram nas moradias e foram realizadas individualmente. Durante as visitas foram feitas caminhadas exploratórias pelos quintais, onde foram apontadas as plantas medicinais e místico-religiosas utilizadas. Nesse momento foram mencionados os nomes populares das espécies, a indicação, o modo de uso e outras informações.

Participaram do estudo mulheres (60\%) e homens (40\%) com idade entre 51 a 89 anos. Quanto à procedência, a maioria (60\%) tem origem o próprio estado de Mato Grosso, seguido de Minas Gerais (20\%), Goiás e Santa Catarina, cada um com percentual de dez. 
A escolaridade variou de Ensino Fundamental (incompleto a completo) a maioria, Ensino Médio, Ensino Superior e Pós-graduação em nível de Mestrado. Com relação ao aspecto religioso $60 \%$ é católica e os demais são espíritas (30\%) e um percentual menor frequenta a umbanda. Além de serem benzedeiras e/ou curandeiros, exercem outras atividades: comerciante, através de fábrica e comércio de velas; artesãos; costureira; do lar; professor universitário; sacerdote umbandista; vendedor; aposentado a maioria.

\section{A prática cultural do benzer e do curar com o uso das plantas}

Conforme Dicionário da Língua Portuguesa, benzer significa abençoar; fazer o sinal-da-cruz para consagrar alguma coisa ao culto divino; invocar a proteção do céu sobre pessoas ou coisas. Nesse contexto, é comum os sacerdotes abençoarem seus fiéis durante as cerimônias religiosas ou mesmo em outros momentos. Também, em algumas regiões é de costume pais, avós, padrinhos e pessoas mais velhas darem a bênção às crianças, fazendo o uso de palavras e gestos.

Segundo Floresta (2016), o princípio básico por trás da benzeção é a ideia de cura física ou espiritual através da palavra, dos gestos e da reza, no qual o benzedor é um intermediário entre Deus e aquele que se submete à cura.

O benzimento é feito preferencialmente na moradia, podendo ser no quintal, na varanda ou num cômodo mais específico destinado a essa prática. Em alguns casos também pode ser feito à distância, quando a pessoa a receber o tratamento não pode ir até o local, geralmente por residir em outra cidade.

Para as práticas de benzeção, a maioria diz ter aprendido o ofício com familiares, em muitos casos mesmo na infância, outros reconhecem que benzer é um dom herdado naturalmente desde o nascimento. Afirmam que estas atividades estão interligadas com ritos e práticas, principalmente, da Igreja Católica. Algumas fazem questão de mostrar seu nicho religioso, uma espécie de altar onde se podem ver imagens de santo como de Nossa Senhora, de Jesus, da Bíblia, entre outras.

Nas rezas ou orações realizadas durante a benzeção são utilizadas formas oficializadas da Igreja Católica, associadas com 
palavras ou expressões de cunho popular. O Pai-Nosso, a AveMaria e outras orações específicas para cada tipo de tratamento foram relatadas pelos entrevistados. Segundo Cunha e Assunção (2017), a força da benzeção não está apenas no ramo, nem apenas nas palavras escritas ou na fé. Se assim fosse, qualquer um poderia benzer, qualquer oração ou santinho poderia valer como benzeção, qualquer um que crê poderia tornar-se um benzedor.

Entretanto, os curandeiros são praticantes principalmente do espiritismo e da umbanda e, segundo relatos conseguem entrar em contato com forças superiores, usam vestimentas especiais e implementos religiosos próprios. Para eles o uso da vela em seus rituais varia, pois, conforme sua cor tem um significado próprio. Por exemplo, a vela branca significa a paz e qualquer pessoa pode acender.

Durante a turnê guiada pelo quintal de uma das residências visitadas observou-se o "espaço sagrado". Conforme o Sr. J.G. relatou, é um local aonde ele vai todas as manhãs e prepara os remédios com suas ervas. Assim, se refere a este lugar como um espaço energético e localizado entre árvores e outras plantas arbustivas e herbáceas e que recebe destas a sombra, a paz, a energia e a tranquilidade.

Diferentemente do que muitos imaginam, que as pessoas não procuram mais tratamentos com benzedores e curandeiros, constatou-se o oposto, pois, durante algumas entrevistas diversas pessoas chegaram para serem benzidas, curadas ou buscarem alguma forma de tratamento para suas enfermidades físicas, emocionais, psíquicas e espirituais. Esses procedimentos não são cobrados, porém, caso as pessoas queiram dar um agrado as benzedeiras, as ofertas são aceitas.

Para o tratamento do Mal de Simioto, os praticantes da medicina popular (benzedeiras e/ou curandeiros) cobram uma taxa de 100 reais (criança) e 200 reais (adulto) para o preparo dos banhos, pois são utilizados vários ingredientes e alguns necessitam ser adquiridos no comércio. O Mal de Simioto (simio = macaco) é o nome popular, em algumas regiões do Brasil, da desnutrição causada em crianças por alergia ao leite de vaca ou a incapacidade de digerir o mesmo. A doença aparece normalmente quando o aleitamento materno é substituído por leite de vaca natural ou em pó. Muitas vezes o intestino de um bebê não produz as enzimas necessárias a digerir esse produto de origem animal e fica desnutrido. Geralmen- 
te desaparece com a volta ao aleitamento materno ou substituição por outro tipo de alimento a critério médico, OMS (2000).

Alguns curandeiros realizam consultas espirituais e também jogam cartas, onde as pessoas querem saber, principalmente, sobre a vida financeira e amorosa, sendo cobrado para realizar essa atividade o valor de 50 reais. De acordo com o conhecimento e o uso de plantas medicinais e místico-religiosas, a maior parte dos entrevistados afirmou que recebeu através do conhecimento tradicional familiar, onde pais e avós têm um papel importante na transmissão do saber tradicional. Fontes externas, como livros, programas de televisão, estudos entre eles o espiritismo também deu sua contribuição.

Essa forma de repassar o etnoconhecimento ocorre geralmente dentro da família ou entre vizinhos mais próximos, onde as pessoas mais velhas transmitem esse saber para as mais novas, seja pela oralidade ou de forma gestual. Assim, as pessoas que têm interesse contribuem para propagar o saber popular ao longo das gerações. Outra maneira de repassar esse conhecimento é através de palestras, como se dá em encontros de Centro Espírita.

Além das plantas utilizam rezas, cruzes, pedras, velas, bebidas, mãos e outros amuletos para praticarem a benzeção e a cura de enfermidades, conforme alguns relatos: "Plantas, pedras, velas, álcool, a fé, o poder das mãos... As velas, de acordo com a cor têm significados diferentes... a vela branca qualquer pessoa pode acender." (Sr. J.G.); "Ensino a fazer garrafada... não faço mais... não tenho tempo de buscar raiz porque tenho que cuidar daqui da fábrica e da loja de velas." (Sr. J.C.V)

“Dou passe, benzo, uso a energia das mãos. Atendo muitas pessoas por telefone... Converso, explico, faço novena aqui e eles fazem lá. Vejo as imagens... mas sou consciente. Uso muito a imagem de Padre Cícero na benzeção de erisipele. Uso vela... a vela preta cura, a branca é paz." (Sr. A.G.O.)

\section{As plantas medicinais e místico-religiosas}

“...Todas as plantas curam, depende da pessoa ter fé..." (Sr. J.G.)

As plantas utilizadas por benzedeiras e curandeiros são também chamadas de 'folhas', 'ervas', 'ramos', recebem este nome de 
acordo com os ritos e procedimentos executados para algum tipo de tratamento de saúde física, mental ou espiritual. Algumas espécies devem ser coletadas seguindo-se rituais complexos para não perder o seu 'poder de cura'. Dessa forma, foram relatados pelos depoentes: "... quando arranca uma raiz, deve tapar o buraco.." "... a 'casca de pau' deve ser tirada de baixo para cima para ter o efeito desejado...".

As procedências das plantas locais são, principalmente, do quintal e das matas. O cultivo das plantas no quintal facilita a sua aquisição para o preparo dos remédios caseiros, bem como nos processos dos rituais religiosos como os benzimentos ou a benzeção, cujo o manejo é relatado que as plantas são coletadas no momento em que são utilizadas para os tratamentos em geral. Portanto, as plantas são usadas ainda frescas e que possivelmente concentram em suas estruturas vegetativas e/ou reprodutivas as suas concentrações farmacológicas, que são potencializadas com as rezas e o sentimento de fé do benzedor ou do curandeiro. Outra maneira de aquisição é através da compra com raizeiros, nas bancas de feiras e da doação ou troca com vizinhos (Figura 2).

As plantas presentes nos quintais são cultivadas em vasos, latas, canteiros ou em covas diretamente no solo. Os vasos e latas podem estar no solo ou fixados em muros, pilares e troncos de árvores. Diversas espécies são cultivadas juntamente com outras, principalmente nos canteiros.

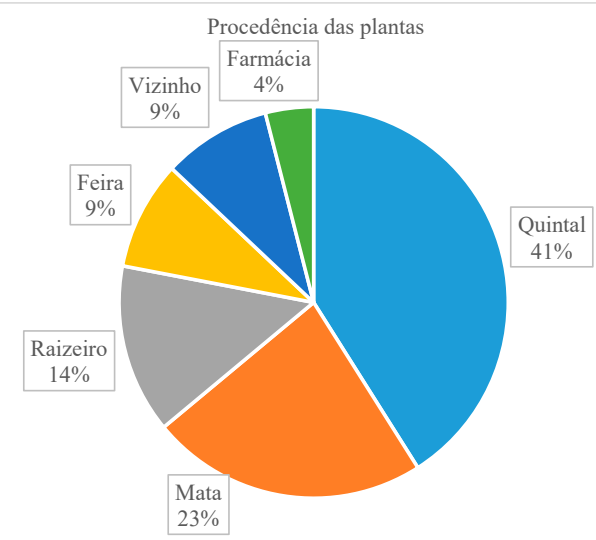

Figura 2. Procedência das plantas utilizadas por benzedeiras e curandeiros, MT. 2016 Fonte: Construção dos Autores 
No total foram citadas 127 espécies pertencentes a 54 famílias botânicas. Destacam-se, pelo maior número de representantes, as famílias Asteraceae (13 espécies), Lamiaceae (12 espécies), Fabaceae (oito espécies) e Poaceae (seis espécies). Número semelhante se comparado com a pesquisa de Novais e Guarim Neto (2011), no município de Castanheira - MT, com 123 espécies e 58 famílias e, no trabalho realizado na comunidade quilombola de Mata Cavalo - MT por Pasa et al. (2015), com 127 espécies distribuídas em 60 famílias botânicas.

As famílias Asteraceae e Lamiaceae contém flavonoides e óleos essenciais com ação anti-inflamatória, bactericida, anestésica e antisséptica (MING, 1995). Nesse sentido, são indicadas as espécies pertencentes a família Asteraceae: arnica (Solidago chilensis Meyen) em casos de machucadura e inflamação; artemísia (Artemisia vulgaris L.) para problemas nos rins e cólica; assa-peixe (Vernonia ferruginea Less.) em casos de febre, gripe, inflamação, úlcera e gastrite; caferana (Vernonia polyanthes (Spreng.) Less.) alivia efeitos da radioterapia, problemas no baço e no fígado. Enquanto para a família Lamiaceae são utilizadas as espécies: alecrim (Cinnamomum zeylanicum Blume) para depressão, problema nos nervos, no coração, pressão alta, benzimento, mal de simioto; boldo (Plectranthus barbatus Andrews) para problemas no sistema digestório; erva cidreira (Melissa officinalis L.) para gases, pressão alta, mal de simioto, problema no estômago, dor no corpo, calmante; hortelã (Mentha villosa Becker) para vermes, disenteria, calmante, mal de simioto.

Algumas plantas são utilizadas em conjunto com outras espécies, como é o caso do alecrim (Cinnamomum zeylanicum Blume.), guiné (Petiveria alliaceae L.) e arruda (Ruta graveolens L.), usadas para benzer; folha seca de alfazema (Lavandula angustifolia Mill.), alecrim (Cinnamomum zeylanicum Blume.) e alho (Allium sativum L.) para fazer defumação e espantar coisas ruins de dentro de casa. Nas garrafadas e nos banhos também são utilizados vários tipos de plantas juntas: casca de romã (Punica granatum L.), barbatimão (Stryphnodendron adstringens Mart), sangra d'água (Croton urucurana Baill.) e noz moscada (Myristica fragans Houtt.) para garrafadas no combate a inflamação de garganta, diarreia e doenças sexualmente transmissíveis; sabugueiro (Sambucus australis Cham. \& Schltdl) e picão (Bidens pilosa L.) no cozimento para banhos em casos de erisipela, sarampo, catapora. 
A Tabela 1 destaca as espécies com seus respectivos nomes populares, nomes científicos, famílias botânicas, indicações terapêuticas, modos de preparo e partes utilizadas.

Algumas plantas possuem valor simbólico e são usadas para o benzimento. Outras plantas têm valor medicinal e são usadas no preparo de chás, garrafadas, emplastos, xaropes. No entanto, há espécies vegetais que exercem uma multiplicidade de funções: medicinal, místico-religiosa, alimentar e ornamental, entre outras.

A maioria das plantas citadas por benzedeiras e curandeiros é utilizada como remédio, sendo a folha a parte vegetal com maior expressividade (57\%). O uso da folha não prejudica o desenvolvimento da planta, assim, contribui para a manutenção da biodiversidade vegetal local e da sustentabilidade ambiental quanto ao uso das mesmas como fitoterápicos para os tratamentos do corpo e da alma.

Quanto ao modo de preparo das plantas o chá foi o mais representativo, citado para 63\% das espécies. Podendo ser utilizado através da ingestão e mesmo para uso externo em banhos ou lavagem de alguma parte do corpo. Contudo, outras formas de preparo e de uso também foram mencionadas como, macerado, compressa, xarope, garrafada, suco, misturado no vinho branco e in natura.

\begin{tabular}{|c|c|c|c|c|c|}
\hline $\begin{array}{l}\text { Nome } \\
\text { Popular }\end{array}$ & Nome Científico & Família & Indicação de Uso & $\begin{array}{c}\text { Modo de } \\
\text { Preparo }\end{array}$ & $\begin{array}{c}\text { Parte } \\
\text { Utilizada }\end{array}$ \\
\hline Açafrão & $\begin{array}{c}\text { Crocus } \\
\text { sativus L. }\end{array}$ & Iridaceae & Febre; gripe & Amassado & Raiz \\
\hline Acerola & $\begin{array}{c}\text { Malpighia } \\
\text { glabra L. }\end{array}$ & Malpighiaceae & Falta de vitamina & Xarope & Fruto \\
\hline Agoniada & $\begin{array}{c}\text { Plumeria } \\
\text { Lancifolia Mul. Arg }\end{array}$ & Apocynaceae & $\begin{array}{c}\text { Cisto; cólica, dor no } \\
\text { parto }\end{array}$ & Garrafada & Casca; flor \\
\hline Alecrim & $\begin{array}{c}\text { Cinnamomum } \\
\text { zeylanicum Blume. }\end{array}$ & Lamiaceae & $\begin{array}{c}\text { Depressão; cal- } \\
\text { mante; problema } \\
\text { de nervos e no } \\
\text { cérebro; coração; } \\
\text { pressão alta; } \\
\text { benzimento; mal de } \\
\text { simioto; tirar inveja }\end{array}$ & $\begin{array}{l}\text { Chá; } \\
\text { banho } \\
\text { (proteção } \\
\text { e descar- } \\
\text { rego) }\end{array}$ & Folha \\
\hline Alfavaca & $\begin{array}{c}\text { Ocimum } \\
\text { basilicum L. }\end{array}$ & Lamiaceae & $\begin{array}{l}\text { Gripe; afta; febre; } \\
\text { mal de simioto }\end{array}$ & $\begin{array}{l}\text { Chá; } \\
\text { cozimen- } \\
\text { to para } \\
\text { banho }\end{array}$ & Folha \\
\hline Alfazema & $\begin{array}{c}\text { Lavandula } \\
\text { angustifolia Mill. }\end{array}$ & Lamiaceae & $\begin{array}{l}\text { Depressão; ner- } \\
\text { vosismo; dor de } \\
\text { cabeça; gripe; } \\
\text { bronquite; sinusite; } \\
\text { mal de simioto }\end{array}$ & $\begin{array}{l}\text { Chá; } \\
\text { cozimen- } \\
\text { to para } \\
\text { banho }\end{array}$ & Folha \\
\hline
\end{tabular}

Continua... 


\begin{tabular}{|c|c|c|c|c|c|}
\hline Algodão & $\begin{array}{l}\text { Gossypium } \\
\text { hirsutum L. }\end{array}$ & Malvaceae & $\begin{array}{l}\text { Pós parto; infla- } \\
\text { mação no útero; } \\
\text { machucadura; } \\
\text { infecção }\end{array}$ & $\begin{array}{l}\text { Chá; ba- } \\
\text { nho; lavar; } \\
\text { sumo }\end{array}$ & Folha \\
\hline Alho & $\begin{array}{c}\text { Allium } \\
\text { sativum L. }\end{array}$ & Liliaceae & $\begin{array}{l}\text { Coceira; purificar o } \\
\text { sangue; infecção; } \\
\text { proteção }\end{array}$ & $\begin{array}{l}\text { Chá; põe } \\
\text { no álcool } \\
\text { para pas- } \\
\text { sar; usar } \\
\text { na roupa }\end{array}$ & Folha; fruto \\
\hline Alho roxo & Allium sp. & Liliaceae & $\begin{array}{c}\text { Derrame; recuperar } \\
\text { movimento }\end{array}$ & Chá & Folha; fruto \\
\hline Amora & Morus nigra L. & Moraceae & Sinusite & $\begin{array}{l}\text { Chá; } \\
\text { banho }\end{array}$ & Folha \\
\hline Arnica & $\begin{array}{c}\text { Solidago } \\
\text { chilensis Meyen }\end{array}$ & Asteraceae & $\begin{array}{l}\text { Machucadura; } \\
\text { inflamação }\end{array}$ & $\begin{array}{l}\text { Chá, in } \\
\text { natura, } \\
\text { compres- } \\
\text { sa; mace- } \\
\text { rado }\end{array}$ & Folha; flor \\
\hline $\begin{array}{l}\text { Arnica do } \\
\text { campo }\end{array}$ & $\begin{array}{l}\text { Lychnophora } \\
\text { ericoides Mart. }\end{array}$ & Asteraceae & $\begin{array}{l}\text { Machucadura; } \\
\text { inflamação; que- } \\
\text { bradura }\end{array}$ & $\begin{array}{c}\text { No álcool; } \\
\text { amassado } \\
\text { (unguen- } \\
\text { to); chá; } \\
\text { põe no } \\
\text { vinho } \\
\text { branco }\end{array}$ & Folha \\
\hline Aroeira & $\begin{array}{c}\text { Myracrodruon } \\
\text { urundeuva Allemão }\end{array}$ & Anacardiaceae & Inflamação & $\begin{array}{l}\text { Lavar no } \\
\text { local }\end{array}$ & Casca \\
\hline Arruda & $\begin{array}{c}\text { Ruta } \\
\text { graveolens L. }\end{array}$ & Rutaceae & $\begin{array}{l}\text { Desmagnetizar; in- } \\
\text { flamação no útero; } \\
\text { benzimento; tirar } \\
\text { inveja; inflamação } \\
\text { nos olhos }\end{array}$ & $\begin{array}{l}\text { Chá para } \\
\text { lavar; } \\
\text { banho } \\
\text { (proteção } \\
\text { e descar- } \\
\text { rego) }\end{array}$ & Folha \\
\hline Artemísia & $\begin{array}{l}\text { Artemisia } \\
\text { vulgaris L. }\end{array}$ & Asteraceae & $\begin{array}{l}\text { Rins; menstruação; } \\
\text { cólica }\end{array}$ & Chá & Folha \\
\hline Assa-peixe & $\begin{array}{c}\text { Vernonia } \\
\text { ferruginea Less. }\end{array}$ & Asteraceae & $\begin{array}{c}\text { Febre; gripe; } \\
\text { inflamação; úlcera e } \\
\text { gastrite }\end{array}$ & Chá; sumo & Folha; broto \\
\hline Babosa & $\begin{array}{l}\text { Alloe vera (L.) } \\
\text { Burm } \mathrm{f} .\end{array}$ & Xanthorrhoaceae & $\begin{array}{l}\text { Dor muscular; he- } \\
\text { morroida; varizes; } \\
\text { câncer; intestino } \\
\text { preso; infecção no } \\
\text { intestino; erisipele; } \\
\text { proteção }\end{array}$ & $\begin{array}{l}\text { Garrafada; } \\
\text { in natura }\end{array}$ & Baba \\
\hline $\begin{array}{l}\text { Bacurizinho } \\
\text { do campo }\end{array}$ & $\begin{array}{c}\text { Garcinia } \\
\text { acuminata Ruiz } \\
\text { et Pav. }\end{array}$ & Clusiaceae & Cisto & Garrafada & Raiz \\
\hline Barbatimão & $\begin{array}{l}\text { Stryphnodendron } \\
\text { adstringens Mart. }\end{array}$ & Fabaceae & $\begin{array}{c}\text { Cisto; cólica; dor no } \\
\text { parto; inflamação; } \\
\text { diarreia; doenças } \\
\text { sexualmente trans- } \\
\text { missíveis; infecção } \\
\text { na mulher }\end{array}$ & $\begin{array}{l}\text { Garrafada; } \\
\text { põe no } \\
\text { vinho } \\
\text { branco; } \\
\text { chá; banho }\end{array}$ & $\begin{array}{l}\text { Casca; entre- } \\
\text { casca }\end{array}$ \\
\hline
\end{tabular}




\begin{tabular}{|c|c|c|c|c|c|}
\hline Baru & Dypterix alata Vog. & Fabaceae & Inflamação & $\begin{array}{l}\text { Lavar no } \\
\text { local }\end{array}$ & Casca \\
\hline Batata & $\begin{array}{c}\text { Solanum } \\
\text { tuberosum L. }\end{array}$ & Solanaceae & Úlcera & Purê & Batata \\
\hline Boldo & $\begin{array}{c}\text { Plectranthus } \\
\text { barbatus Andrews }\end{array}$ & Lamiaceae & Estômago; fígado & $\begin{array}{l}\text { Triturado } \\
\text { ou amas- } \\
\text { sado e } \\
\text { misturado } \\
\text { na água }\end{array}$ & Folha \\
\hline Buchinha & $\begin{array}{c}\text { Luffa aegyptiaca } \\
\text { Mill. }\end{array}$ & Cucurbitaceae & $\begin{array}{l}\text { Gripe; bronquite; } \\
\text { sinusite }\end{array}$ & $\begin{array}{l}\text { Chá; ba- } \\
\text { nho; põe } \\
\text { no álcool }\end{array}$ & Fruto \\
\hline Caferana & $\begin{array}{c}\text { Vernonia } \\
\text { polyanthes } \\
\text { (Spreng.) Less. }\end{array}$ & Asteraceae & $\begin{array}{l}\text { Alivia efeitos da } \\
\text { radioterapia; baço; } \\
\text { fígado }\end{array}$ & Chá & Folha \\
\hline Camomila & $\begin{array}{c}\text { Matricaria recutita } \\
\text { L. }\end{array}$ & Asteraceae & $\begin{array}{c}\text { Calmante para } \\
\text { criança }\end{array}$ & Chá & Flor \\
\hline Cana caiana & $\begin{array}{l}\text { Saccharum } \\
\text { officinarum L. }\end{array}$ & Poaceae & Pressão alta & Chá & Folha \\
\hline Canela & $\begin{array}{c}\text { Cinnamomum } \\
\text { zeylanicum Blume. }\end{array}$ & Lauraceae & $\begin{array}{l}\text { Fortalecer; mens- } \\
\text { truação; pulmões; } \\
\text { mal de simioto }\end{array}$ & $\begin{array}{l}\text { Chá; } \\
\text { banho }\end{array}$ & Casca \\
\hline $\begin{array}{l}\text { Caninha-do- } \\
\text { brejo }\end{array}$ & $\begin{array}{l}\text { Costus spicatus } \\
\text { (Jacq.) Sw }\end{array}$ & Costaceae & Rins & $\begin{array}{l}\text { Amassa } \\
\text { e põe na } \\
\text { água; chá }\end{array}$ & Talo \\
\hline $\begin{array}{l}\text { Capim } \\
\text { cidreira }\end{array}$ & $\begin{array}{c}\text { Cymbopogon } \\
\text { citratus (DC.) Stapf }\end{array}$ & Poaceae & $\begin{array}{l}\text { Resfriado; gripe; } \\
\text { pressão alta; } \\
\text { calmante }\end{array}$ & $\begin{array}{l}\text { Chá; cozi- } \\
\text { mento }\end{array}$ & $\begin{array}{l}\text { Toda planta; } \\
\text { folha }\end{array}$ \\
\hline Carobinha & $\begin{array}{c}\text { Jacaranda } \\
\text { semiserrata Cham. }\end{array}$ & Bignoniaceae & $\begin{array}{c}\text { Depurativo do } \\
\text { sangue; fígado; } \\
\text { problema nos rins; } \\
\text { coceira }\end{array}$ & $\begin{array}{l}\text { Põe na } \\
\text { água para } \\
\text { beber; } \\
\text { chá; banho }\end{array}$ & Raiz \\
\hline Carqueja & $\begin{array}{c}\text { Baccharis trimera } \\
\text { Less. DC. }\end{array}$ & Asteraceae & $\begin{array}{c}\text { Diabete; problemas } \\
\text { no estômago e no } \\
\text { fígado }\end{array}$ & Chá & Folha \\
\hline $\begin{array}{l}\text { Carrapixo de } \\
\text { ovelha }\end{array}$ & Bidens pilosa $\mathrm{L}$. & Asteraceae & $\begin{array}{l}\text { Icterícia; fígado; } \\
\text { infecção }\end{array}$ & $\begin{array}{l}\text { Chá; } \\
\text { banho }\end{array}$ & Toda planta \\
\hline Cebola & Allium cepa $\mathrm{L}$. & Liliaceae & Sinusite & Chá & Cebola \\
\hline $\begin{array}{l}\text { Chapéu de } \\
\text { couro }\end{array}$ & $\begin{array}{l}\text { Echinodorus } \\
\text { grandiflorus (Cham. } \\
\text { \& Schltdl.) Micheli }\end{array}$ & Alismataceae & $\begin{array}{l}\text { Rins; depurativo; } \\
\text { pressão alta; } \\
\text { coração }\end{array}$ & Chá & Folha \\
\hline Cipó imbé & $\begin{array}{c}\text { Philodendron imbe } \\
\text { Schott }\end{array}$ & Araceae & $\begin{array}{c}\text { Reumatismo; burci- } \\
\text { te; erisipela }\end{array}$ & $\begin{array}{l}\text { Amassado } \\
\text { e no ál- } \\
\text { cool; chá }\end{array}$ & $\begin{array}{l}\text { Caule; folha; } \\
\text { casca }\end{array}$ \\
\hline Citronela & $\begin{array}{c}\text { Cymbopogon } \\
\text { winterianus Jowitt } \\
\text { ex Bor }\end{array}$ & Poaceae & Repelente & & Folha \\
\hline Coco babaçu & Orbignya speciosa & Arecaceae & Problema de coluna & $\begin{array}{l}\text { Chá; } \\
\text { torrado }\end{array}$ & $\begin{array}{l}\text { Casca do } \\
\text { fruto }\end{array}$ \\
\hline
\end{tabular}




\begin{tabular}{|c|c|c|c|c|c|}
\hline Colônia & $\begin{array}{l}\text { Alpinia zerumbet } \\
\text { (Pers.) B. L. Burtt } \\
\text { \& R. M. }\end{array}$ & Zingiberaceae & $\begin{array}{c}\text { Pressão alta; } \\
\text { gripe; febre; dor de } \\
\text { cabeça; aceleração } \\
\text { no coração; mal de } \\
\text { simioto }\end{array}$ & $\begin{array}{l}\text { Chá; } \\
\text { banho }\end{array}$ & Folha \\
\hline $\begin{array}{l}\text { Comigo-nin- } \\
\text { guém-pode }\end{array}$ & $\begin{array}{l}\text { Dieffenbachia } \\
\text { amoena Bull. }\end{array}$ & Araceae & $\begin{array}{c}\text { Tirar inveja; pro- } \\
\text { teção }\end{array}$ & $\begin{array}{c}\text { Banho de } \\
\text { descarrego }\end{array}$ & Toda planta \\
\hline Confrei & $\begin{array}{l}\text { Symphytum } \\
\text { officinale L. }\end{array}$ & Boraginaceae & $\begin{array}{l}\text { Inflamação; machu- } \\
\text { cado; cicatrização }\end{array}$ & Chá & Folha \\
\hline $\begin{array}{l}\text { Conta de } \\
\text { lágrima } \\
\text { de nossa } \\
\text { senhora } \\
\end{array}$ & Coix lacryma-jobi L. & Poaceae & Pedra nos rins & $\begin{array}{l}\text { Soca no } \\
\text { pilão e } \\
\text { ferve; chá }\end{array}$ & Semente \\
\hline Copaíba & $\begin{array}{c}\text { Copaifera } \\
\text { langsdorffii Desf. }\end{array}$ & Fabaceae & $\begin{array}{l}\text { Gripe; tuberculose; } \\
\text { câncer na garganta }\end{array}$ & $\begin{array}{c}\text { Retira o } \\
\text { óleo }\end{array}$ & Caule; óleo \\
\hline Couve & Brassica oleracea $\mathrm{L}$. & Brassicaceae & Úlcera & $\begin{array}{l}\text { Sumo ou } \\
\text { comer }\end{array}$ & Folha \\
\hline $\begin{array}{l}\text { Douradinha } \\
\text { do campo }\end{array}$ & $\begin{array}{c}\text { Waltheria } \\
\text { douradinha A. } \\
\text { St.-Hil. }\end{array}$ & Sterculiaceae & $\begin{array}{l}\text { Depurtivo; limpar } \\
\text { a pele; diurético; } \\
\text { inflamação nos rins } \\
\text { e bexiga }\end{array}$ & Chá & Folha; casca \\
\hline Dracena & Dracaena sp. & Asparagaceae & Limpar o ar & & Toda planta \\
\hline Embaúba & $\begin{array}{c}\text { Cetropia hololeuca } \\
\text { Miq. }\end{array}$ & Urticaceae & $\begin{array}{l}\text { Tosse; asma; cica- } \\
\text { trizante }\end{array}$ & $\begin{array}{c}\text { Chá; xaro- } \\
\text { pe; com- } \\
\text { pressa }\end{array}$ & $\begin{array}{c}\text { Folha; caule; } \\
\text { fruto }\end{array}$ \\
\hline Emburana & $\begin{array}{c}\text { Commiphora } \\
\text { leptophloeos } \\
\text { (Mart.) J.B. Gillett }\end{array}$ & Burseraceae & $\begin{array}{c}\text { Reumatismo; asma; } \\
\text { gripe; bronquite; } \\
\text { tosse }\end{array}$ & Chá & $\begin{array}{c}\text { Casca; } \\
\text { semente }\end{array}$ \\
\hline Erva cideira & $\begin{array}{c}\text { Melissa } \\
\text { officinalis L. }\end{array}$ & Lamiaceae & $\begin{array}{c}\text { Gases; pressão alta; } \\
\text { mal de simioto; pro- } \\
\text { blema no estôma- } \\
\text { go; dor no corpo; } \\
\text { calmante }\end{array}$ & $\begin{array}{l}\text { Chá; } \\
\text { banho }\end{array}$ & Folha \\
\hline $\begin{array}{l}\text { Erva de } \\
\text { passarinho } \\
\text { ou vassou- } \\
\text { rinha }\end{array}$ & Struthanthus sp. & Loranthaceae & $\begin{array}{c}\text { Para os pulmões; } \\
\text { bronquite; asma; } \\
\text { infecção no útero; } \\
\text { febre }\end{array}$ & $\begin{array}{l}\text { Xarope; } \\
\text { chá; com- } \\
\text { pressa }\end{array}$ & Casca \\
\hline $\begin{array}{l}\text { Erva-de-san- } \\
\text { ta- maria }\end{array}$ & $\begin{array}{l}\text { Coronopus didymus } \\
\text { (L.) Smith. }\end{array}$ & Chenopodiaceae & $\begin{array}{l}\text { Vermes; inflama- } \\
\text { ção; machucadura; } \\
\text { quebradura; mal de } \\
\text { simioto }\end{array}$ & $\begin{array}{l}\text { Chá; } \\
\text { banho }\end{array}$ & Folha \\
\hline $\begin{array}{l}\text { Erva-de-são- } \\
\text { joão }\end{array}$ & $\begin{array}{c}\text { Hypericum } \\
\text { perforatum L. }\end{array}$ & Hyperaceae & $\begin{array}{c}\text { Cisto; insonia; } \\
\text { nervosismo; epilep- } \\
\text { sia; desmaio; dor de } \\
\text { cabeça }\end{array}$ & Garrafada & Folha \\
\hline $\begin{array}{l}\text { Escada-de- } \\
\text { macaco }\end{array}$ & $\begin{array}{c}\text { Bauhinia angulosa } \\
\text { Vogel. }\end{array}$ & Fabaceae & $\begin{array}{l}\text { Problemas de } \\
\text { coluna }\end{array}$ & $\begin{array}{c}\text { Chá; } \\
\text { colocar no } \\
\text { álcool }\end{array}$ & Caule \\
\hline $\begin{array}{l}\text { Espada-de- } \\
\text { iansã }\end{array}$ & Sanseveria sp. & Asparagaceae & $\begin{array}{l}\text { Guardião; tirar } \\
\text { inveja }\end{array}$ & $\begin{array}{l}\text { Banho } \\
\text { (descarre- } \\
\text { go) }\end{array}$ & Toda planta \\
\hline
\end{tabular}




\begin{tabular}{|c|c|c|c|c|c|}
\hline $\begin{array}{l}\text { Espada-de- } \\
\text { ogum }\end{array}$ & Sanseveria sp. & Asparagaceae & $\begin{array}{l}\text { Guardião; tirar } \\
\text { inveja }\end{array}$ & $\begin{array}{l}\text { Banho } \\
\text { (descarre- } \\
\text { go) }\end{array}$ & Toda planta \\
\hline $\begin{array}{l}\text { Espada-de- } \\
\text {-são-jorge }\end{array}$ & $\begin{array}{c}\text { Sansevieria } \\
\text { trifasciata Prain }\end{array}$ & Asparagaceae & $\begin{array}{l}\text { Guardião; tirar } \\
\text { inveja }\end{array}$ & $\begin{array}{c}\text { Banho } \\
\text { (descarre- } \\
\text { go) }\end{array}$ & Toda planta \\
\hline $\begin{array}{l}\text { Espinheira } \\
\text { santa }\end{array}$ & $\begin{array}{c}\text { Maytenus } \\
\text { aquifolium Mart. }\end{array}$ & Celastraceae & $\begin{array}{c}\text { Úlcera; gastrite; } \\
\text { problemas no } \\
\text { fígado; anemia; } \\
\text { câncer }\end{array}$ & $\begin{array}{l}\text { Chá; com- } \\
\text { pressa }\end{array}$ & Folha \\
\hline Eucalipto & $\begin{array}{c}\text { Eucalyptus globulus } \\
\text { Labill. }\end{array}$ & Myrtaceae & $\begin{array}{l}\text { Febre; gripe; bron- } \\
\text { quite; sinusite; mal } \\
\text { de simioto }\end{array}$ & $\begin{array}{l}\text { Chá; no } \\
\text { álcool; } \\
\text { banho } \\
\text { (descarre- } \\
\text { go, prote- } \\
\text { ção) }\end{array}$ & Folha \\
\hline Folha santa & $\begin{array}{c}\text { Kalanchoe } \\
\text { brasiliensis } \\
\text { Cambess. }\end{array}$ & Crassulaceae & Infecção & Chá & Folha \\
\hline Fortuna & $\begin{array}{c}\text { Bryophyllum } \\
\text { pinnatum (Lam.) } \\
\text { Oken } \\
\end{array}$ & Crassulaceae & $\begin{array}{c}\text { Bronquite; azia; } \\
\text { enxaqueca; diarreia }\end{array}$ & Chá & Folha \\
\hline Gengibre & $\begin{array}{c}\text { Zingiber officinale } \\
\text { Roscoe }\end{array}$ & Zingiberaceae & Gripe; resfriado & Chá & Raiz \\
\hline Gervão & $\begin{array}{c}\text { Stachytarpheta } \\
\text { cayennensis (Rich.) } \\
\text { Vahl }\end{array}$ & Verbenaceae & $\begin{array}{l}\text { Fígado; gordura no } \\
\text { fígado; inflamação }\end{array}$ & Chá & Folha; galho \\
\hline Goiaba & Psidium guajava $\mathrm{L}$. & Myrtaceae & Desinteria & Chá & Broto \\
\hline Guaco & $\begin{array}{l}\text { Mikania glomerata } \\
\text { Spreng. }\end{array}$ & Asteraceae & $\begin{array}{c}\text { Gripe; tosse; infec- } \\
\text { ção de garganta; } \\
\text { bronquite }\end{array}$ & $\begin{array}{l}\text { Chá; } \\
\text { xarope }\end{array}$ & Folha \\
\hline Guaimbê & $\begin{array}{c}\text { Philodendron } \\
\text { bipinnatifidum } \\
\text { Schott. } \\
\end{array}$ & Araceae & $\begin{array}{l}\text { Erisipele; úlcera; } \\
\text { inflamação }\end{array}$ & $\begin{array}{c}\text { Banho; } \\
\text { cha; com- } \\
\text { pressa }\end{array}$ & Folha; casca \\
\hline Guiné ou tipi & $\begin{array}{c}\text { Petiveria alliaceae } \\
\text { L. }\end{array}$ & Phytolaccaceae & $\begin{array}{l}\text { Reumatismo; } \\
\text { cãibra; benzimento; } \\
\text { mal de simioto }\end{array}$ & $\begin{array}{c}\text { Chá; } \\
\text { banho; } \\
\text { põe no } \\
\text { vinho ou } \\
\text { no biotôni- } \\
\text { co; banho } \\
\text { (descarre- } \\
\text { go) } \\
\end{array}$ & Raiz; folha \\
\hline Hortelã & $\begin{array}{c}\text { Mentha villosa } \\
\text { Becker }\end{array}$ & Lamiaceae & $\begin{array}{c}\text { Vermes; desinteria; } \\
\text { calmante; mal de } \\
\text { simioto }\end{array}$ & $\begin{array}{c}\text { Chá e cozi- } \\
\text { mento }\end{array}$ & Folha \\
\hline $\begin{array}{l}\text { Hortelã } \\
\text { gordo }\end{array}$ & $\begin{array}{c}\text { Coleus amboinicus } \\
\text { Lour. }\end{array}$ & Lamiaceae & $\begin{array}{c}\text { Gripe; febre; rou- } \\
\text { quidão }\end{array}$ & $\begin{array}{c}\text { Chá; amas- } \\
\text { sado }\end{array}$ & Folha \\
\hline Hortelãzinho & $\begin{array}{c}\text { Mentha pulegium } \\
\text { L. }\end{array}$ & Lamiaceae & $\begin{array}{c}\text { Tosse; gripe; cal- } \\
\text { mante; vermes; chá } \\
\text { para criança }\end{array}$ & $\begin{array}{l}\text { Xarope; } \\
\text { chá }\end{array}$ & Folha \\
\hline Inharé & Castilla ulei Warb. & Moraceae & $\begin{array}{l}\text { Cisto; cólica; dor no } \\
\text { parto }\end{array}$ & Garrafada & Raiz \\
\hline
\end{tabular}




\begin{tabular}{|c|c|c|c|c|c|}
\hline Jaborandi & $\begin{array}{c}\text { Pilocarpus } \\
\text { pennatifolius Lem. }\end{array}$ & Rutaceae & $\begin{array}{c}\text { Menstruação } \\
\text { atrasada }\end{array}$ & Chá & Folha \\
\hline Jaca & $\begin{array}{c}\text { Artocarpus } \\
\text { integrifolia } \mathrm{L} . \mathrm{f} .\end{array}$ & Moraceae & Fortalecer os ossos & $\begin{array}{c}\text { Bater a } \\
\text { semente } \\
\text { seca com } \\
\text { leite }\end{array}$ & Semente \\
\hline Jenipapo & $\begin{array}{c}\text { Genipa americana } \\
\text { L. }\end{array}$ & Rubiaceae & Quebradura & Emplasto & Casca \\
\hline Jurema & $\begin{array}{l}\text { Mimosa hostilis } \\
\text { (C.Mart.) Benth }\end{array}$ & Fabaceae & $\begin{array}{c}\text { Dor de cabeça; } \\
\text { insonia; descarrego }\end{array}$ & $\begin{array}{c}\text { Banho; } \\
\text { defuma- } \\
\text { dor; banho } \\
\text { de descar- } \\
\text { rego }\end{array}$ & Folha; casca \\
\hline Jurubeba & $\begin{array}{c}\text { Solanum } \\
\text { paniculatum L. }\end{array}$ & Solanaceae & Febre & Chá & $\begin{array}{l}\text { Folha; flor; } \\
\text { fruto }\end{array}$ \\
\hline Laranja & $\begin{array}{c}\text { Citrus sinensis L. } \\
\text { Osbeck }\end{array}$ & Rutaceae & $\begin{array}{c}\text { Febre; gripe; dor no } \\
\text { corpo; constipação }\end{array}$ & Chá; suco & Folha; fruto \\
\hline Levante & Mentha viridis $L$. & Lamiaceae & Mal de simioto & $\begin{array}{c}\text { Cozimento } \\
\text { e chá; } \\
\text { banho }\end{array}$ & Folha \\
\hline Limão & $\begin{array}{c}\text { Citrus limon (L.) } \\
\text { Osbeck }\end{array}$ & Rutaceae & Gripe & Chá; suco & Folha; fruto \\
\hline $\begin{array}{l}\text { Lírio de são } \\
\text { josé }\end{array}$ & $\begin{array}{l}\text { Hemerocallis } \\
\text { flava } \mathrm{L} .\end{array}$ & Liliaceae & Dor de cabeça & Banho & Toda a planta \\
\hline Losna & $\begin{array}{c}\text { Artemisia } \\
\text { absinthium L. }\end{array}$ & Asteraceae & $\begin{array}{l}\text { Febre; vermes; } \\
\text { anemia; cólica }\end{array}$ & $\begin{array}{c}\text { Chá; com- } \\
\text { pressa }\end{array}$ & Folha; flor \\
\hline Mamão & Carica papaya L. & Caricaceae & Triglicérides & Chá & Flor \\
\hline Mamona & $\begin{array}{c}\text { Ricinus communis } \\
\text { L. }\end{array}$ & Euphorbiaceae & Vermes & Óleo & Fruto \\
\hline Manacá & $\begin{array}{c}\text { Brunfelsia hopeana } \\
\text { Benth. }\end{array}$ & Solanaceae & $\begin{array}{c}\text { Depurativo do } \\
\text { sangue, fígado, } \\
\text { problema nos rins }\end{array}$ & $\begin{array}{c}\text { Colocar na } \\
\text { pinga ou } \\
\text { no vinho } \\
\text { branco }\end{array}$ & Raiz \\
\hline Manga & Mangifera indica $\mathrm{L}$. & Anacardiaceae & Falta de vitamina & Xarope & Folha \\
\hline Mangaba & $\begin{array}{l}\text { Lafoensia pacari } \\
\text { (Saint-Hilaire) }\end{array}$ & Lythraceae & Circulação & Chá & Folha \\
\hline Manjericão & $\begin{array}{c}\text { Ocimum basilicum } \\
\text { L. }\end{array}$ & Lamiaceae & $\begin{array}{c}\text { Gases; problemas } \\
\text { digestivos; mal de } \\
\text { simioto }\end{array}$ & $\begin{array}{c}\text { Chá; } \\
\text { cozimen- } \\
\text { to para } \\
\text { banho } \\
\text { (proteção) } \\
\end{array}$ & Folha \\
\hline Maracujá & $\begin{array}{l}\text { Passiflora edulis } \\
\text { Sims. }\end{array}$ & Passifloraceae & Diabete & $\begin{array}{c}\text { Deixa } \\
\text { secar a } \\
\text { casca e faz } \\
\text { o pó para } \\
\text { misturar } \\
\text { na comida } \\
\end{array}$ & $\begin{array}{l}\text { Casca da } \\
\text { fruta }\end{array}$ \\
\hline Margoso & $\begin{array}{l}\text { Digitaria insularis } \\
\text { (L.) Fedde }\end{array}$ & Poaceae & Estômago e diabete & $\begin{array}{l}\text { Põe na } \\
\text { água }\end{array}$ & Caule; folha \\
\hline
\end{tabular}




\begin{tabular}{|c|c|c|c|c|c|}
\hline Mastruz & $\begin{array}{l}\text { Chenopodium } \\
\text { ambrosioides L. }\end{array}$ & Brassicaceae & $\begin{array}{l}\text { Machucadura; } \\
\text { quebradura }\end{array}$ & $\begin{array}{l}\text { Amassar, } \\
\text { colocar sal } \\
\text { e enfaixar }\end{array}$ & Folha \\
\hline Melancia & $\begin{array}{l}\text { Citrullus lanatus } \\
\text { (Thunb.) Matsum. } \\
\text { \& Nakai }\end{array}$ & Cucurbitaceae & Impotência sexual & Chá & $\begin{array}{l}\text { Semente; } \\
\text { casca da } \\
\text { fruta }\end{array}$ \\
\hline $\begin{array}{l}\text { Melão de } \\
\text { são caetano }\end{array}$ & $\begin{array}{l}\text { Momordia } \\
\text { charantia L. }\end{array}$ & Cucurbitaceae & $\begin{array}{l}\text { Reduz tumor; baixa } \\
\text { a glicose; diabete; } \\
\text { dengue; gripe }\end{array}$ & $\begin{array}{c}\text { Chá; suco; } \\
\text { banho }\end{array}$ & $\begin{array}{c}\text { Folha; fruto; } \\
\text { raiz }\end{array}$ \\
\hline Mentrasto & $\begin{array}{c}\text { Ageratum } \\
\text { conyzoides L. }\end{array}$ & Asteraceae & Cólica menstrual & Chá & Folha \\
\hline Metiolate & $\begin{array}{c}\text { Jatropha multipida } \\
\text { L. }\end{array}$ & Euphorbiaceae & $\begin{array}{c}\text { Cicatrizante; infla- } \\
\text { mação }\end{array}$ & $\begin{array}{c}\text { Cha; com- } \\
\text { pressa }\end{array}$ & Folha e fruto \\
\hline Milho & Zea mays L. & Poaceae & Pedra nos rins & Chá & $\begin{array}{l}\text { Cabelo do } \\
\text { milho }\end{array}$ \\
\hline Mirra & $\begin{array}{c}\text { Commiphora } \\
\text { myrrha (T. Nees) } \\
\text { Engl. }\end{array}$ & Burseraceae & $\begin{array}{l}\text { Dores muscurales; } \\
\text { repelente }\end{array}$ & $\begin{array}{l}\text { Chá; com- } \\
\text { pressa; } \\
\text { incenso }\end{array}$ & Folha \\
\hline $\begin{array}{l}\text { Nó de } \\
\text { cachorro }\end{array}$ & $\begin{array}{c}\text { Heteropteris } \\
\text { aphrodisiaca } 0 . \\
\text { Mach. }\end{array}$ & Malpighiaceae & $\begin{array}{c}\text { Cisto; problemas } \\
\text { de nervos, cérebro; } \\
\text { sangue }\end{array}$ & $\begin{array}{c}\text { Garrafada; } \\
\text { mistura } \\
\text { no vinho } \\
\text { branco ou } \\
\text { na pinga }\end{array}$ & Raiz \\
\hline $\begin{array}{l}\text { Noz mos- } \\
\text { cada }\end{array}$ & $\begin{array}{c}\text { Myristica fragans } \\
\text { Houtt. }\end{array}$ & Miristicaceae & $\begin{array}{c}\text { Inflamação; } \\
\text { diarreia; doenças } \\
\text { sexualmente trans- } \\
\text { missíveis }\end{array}$ & Garrafada & Semente \\
\hline $\begin{array}{l}\text { Ora-pro- } \\
\text {-nóbis }\end{array}$ & $\begin{array}{c}\text { Pereskia aculeata } \\
\text { Mill. }\end{array}$ & Cactaceae & $\begin{array}{c}\text { Proteína; cistite; } \\
\text { úlcera }\end{array}$ & $\begin{array}{l}\text { Chá; in } \\
\text { natura }\end{array}$ & Folha \\
\hline $\begin{array}{l}\text { Pau de } \\
\text { tetente }\end{array}$ & Quassia amara L. & Simaroubaceae & $\begin{array}{l}\text { Estômago e fígado; } \\
\text { vermífugo; anti-in- } \\
\text { flamatório }\end{array}$ & $\begin{array}{l}\text { Põe na } \\
\text { água para } \\
\text { beber }\end{array}$ & Caule; casca \\
\hline Pau ferro & $\begin{array}{c}\text { Caesalpinia ferrea } \\
\text { Mart. }\end{array}$ & Fabaceae & $\begin{array}{l}\text { Cérebro; colesterol; } \\
\text { coração, anemia }\end{array}$ & $\begin{array}{c}\text { Põe na } \\
\text { água ou no } \\
\text { vinho }\end{array}$ & Vagem \\
\hline Pequi & $\begin{array}{l}\text { Caryocar } \\
\text { brasiliense } \\
\text { Cambess. }\end{array}$ & Caryocaraceae & Bronquite crônica & Chá & Casca \\
\hline Picão & Bidens pilosa L. & Asteraceae & Icterícia; erisipele & $\begin{array}{c}\text { Chá para } \\
\text { banho }\end{array}$ & Folha; flor \\
\hline Pimenta & $\begin{array}{c}\text { Capsicum } \\
\text { albescens Kuntze }\end{array}$ & Solanaceae & $\begin{array}{c}\text { Mau olhado; } \\
\text { proteção }\end{array}$ & & Toda planta \\
\hline Pinhão roxo & $\begin{array}{c}\text { Jatropha } \\
\text { gossypiifolia L. }\end{array}$ & Euphorbiaceae & $\begin{array}{c}\text { Guardião; cicatri- } \\
\text { zante }\end{array}$ & Chá & Folha; fruto \\
\hline Pitanga & Eugenia uniflora L. & Myrtaceae & Pressão alta & Chá & Folha \\
\hline Poejo & $\begin{array}{c}\text { Mentha pulegium } \\
\text { L. }\end{array}$ & Lamiaceae & $\begin{array}{c}\text { Recém-nascido; mal } \\
\text { de simioto; para } \\
\text { criança }\end{array}$ & $\begin{array}{c}\text { Xarope; } \\
\text { chá; banho }\end{array}$ & Folha \\
\hline $\begin{array}{l}\text { Quebra- } \\
\text { pedra }\end{array}$ & $\begin{array}{c}\text { Phyllanthus } \\
\text { orbiculatus Rich. }\end{array}$ & Phyllanthaceae & Rins & Chá & Folha \\
\hline
\end{tabular}




\begin{tabular}{|c|c|c|c|c|c|}
\hline Quiabo & $\begin{array}{l}\text { Abelmoschus } \\
\text { esculentus (L.) } \\
\text { Moench }\end{array}$ & Malvaceae & Diabete & $\begin{array}{c}\text { Bater a } \\
\text { baba para } \\
\text { beber }\end{array}$ & Baba \\
\hline Quina & $\begin{array}{c}\text { Strychnos } \\
\text { pseudoquina A. } \\
\text { St. - Hil. }\end{array}$ & Loganiaceae & $\begin{array}{c}\text { Anemia; depurativo } \\
\text { do sangue; inflama- } \\
\text { ção; amarelão }\end{array}$ & $\begin{array}{c}\text { No vinho; } \\
\text { chá; coloca } \\
\text { na comida }\end{array}$ & $\begin{array}{c}\text { Casca; entre- } \\
\text { casca }\end{array}$ \\
\hline $\begin{array}{l}\text { Raiz de } \\
\text { perdiz }\end{array}$ & $\begin{array}{c}\text { Croton } \\
\text { antisyphiliticus } \\
\text { Mart }\end{array}$ & Euphorbiaceae & $\begin{array}{l}\text { Infecção, úlcera, } \\
\text { gastrite }\end{array}$ & $\begin{array}{c}\text { Cha; } \\
\text { coloca } \\
\text { no vinho } \\
\text { branco } \\
\end{array}$ & Raiz \\
\hline Romã & Punica granatum L. & Punicaceae & $\begin{array}{c}\text { Diabete; inflama- } \\
\text { ção na garganta; } \\
\text { diarreia; doença } \\
\text { sexualmente trans- } \\
\text { missível; inflamação }\end{array}$ & $\begin{array}{l}\text { Chá; garra- } \\
\text { fada; lavar } \\
\text { a parte }\end{array}$ & Casca; raiz \\
\hline Rosa branca & Rosa alba L. & Rosaceae & Fluidificar & Banho & Flor \\
\hline Roseta & $\begin{array}{c}\text { Soliva } \\
\text { pterosperma (Juss.) } \\
\text { Less. }\end{array}$ & Asteraceae & $\begin{array}{c}\text { Nervos; cérebro; } \\
\text { coração }\end{array}$ & $\begin{array}{l}\text { Põe no } \\
\text { vinho } \\
\text { branco, } \\
\text { pinga ou } \\
\text { na água }\end{array}$ & Raiz \\
\hline Sabugueiro & $\begin{array}{l}\text { Sambucus australis } \\
\text { Cham. \& Schltdl }\end{array}$ & Adoxaceae & $\begin{array}{c}\text { Catapora; sarampo; } \\
\text { erisipele; mal de } \\
\text { simioto }\end{array}$ & $\begin{array}{l}\text { Chá; } \\
\text { banho }\end{array}$ & Folha; flor \\
\hline Samambaia & $\begin{array}{c}\text { Pleopeltis } \\
\text { pleopeltifolia } \\
\text { (Raddi) Alston }\end{array}$ & Polypodiaceae & Gripe & Chá & Folha \\
\hline $\begin{array}{l}\text { Sangra } \\
\text { d'água }\end{array}$ & $\begin{array}{l}\text { Croton urucurana } \\
\text { Baill. }\end{array}$ & Euphorbiaceae & $\begin{array}{c}\text { Ferida no útero } \\
\text { e ovários; sífilis; } \\
\text { inflamação; doença } \\
\text { sexualmente trans- } \\
\text { missível } \\
\end{array}$ & $\begin{array}{l}\text { Colocar no } \\
\text { vinho para } \\
\text { beber; } \\
\text { garrafada }\end{array}$ & Leite; casca \\
\hline Sene & $\begin{array}{c}\text { Cassia angustifolia } \\
\text { Vahl }\end{array}$ & Fabaceae & $\begin{array}{l}\text { Intestino preso; } \\
\text { mesntruação enca- } \\
\text { Ihada; cólica }\end{array}$ & Chá & Folha \\
\hline $\begin{array}{l}\text { Sete-san- } \\
\text { grias }\end{array}$ & $\begin{array}{c}\text { Cuphea } \\
\text { carthagenensis } \\
\text { (Jacq.) J.F. Macbr. }\end{array}$ & Lythraceae & $\begin{array}{l}\text { Pressão alta; inso- } \\
\text { nia; depurativo }\end{array}$ & Chá & Folha e flor \\
\hline Sucupira & $\begin{array}{c}\text { Bowdichia } \\
\text { virgilioides Kunth }\end{array}$ & Fabaceae & $\begin{array}{l}\text { Inflamação de gar- } \\
\text { ganta; problema de } \\
\text { estômago e fígado }\end{array}$ & $\begin{array}{c}\text { Amassar e } \\
\text { colocar na } \\
\text { água para } \\
\text { beber } \\
\end{array}$ & $\begin{array}{l}\text { Semente; } \\
\text { casca }\end{array}$ \\
\hline Tansagem & Plantago major L. & Plantaginaceae & Infecção & Chá & Folha \\
\hline Terramicina & $\begin{array}{c}\text { Alternanthera } \\
\text { brasiliana (L.) } \\
\text { Kuntze }\end{array}$ & Amaranthaceae & Inflamação & Chá & Folha \\
\hline Tilia & Tilia cordata Mill & Malvaceae & $\begin{array}{l}\text { Pressão alta; ner- } \\
\text { vos; bronquite }\end{array}$ & Chá & Folha; flor \\
\hline Tomate & $\begin{array}{c}\text { Solanum } \\
\text { lycopersicum L. }\end{array}$ & Solanaceae & $\begin{array}{l}\text { Vento virado; que- } \\
\text { brante; reumatismo } \\
\text { agudo }\end{array}$ & $\begin{array}{l}\text { Benzer; } \\
\text { banho; } \\
\text { passar no } \\
\text { local }\end{array}$ & $\begin{array}{l}\text { Folha; toda } \\
\text { planta }\end{array}$ \\
\hline
\end{tabular}




\begin{tabular}{l|c|c|c|c|c}
\hline Uva & Vitis sp. & Vitaceae & $\begin{array}{c}\text { Diminuir a men- } \\
\text { truação }\end{array}$ & Chá & Folha \\
\hline Vergateza & $\begin{array}{c}\text { Anemopaegma } \\
\text { arvense (Vell.) } \\
\text { Stellfeld ex J.F. } \\
\text { Souza }\end{array}$ & Bignoniaceae & $\begin{array}{c}\text { Fortalecer os } \\
\text { nervos; impotência } \\
\text { sexual }\end{array}$ & $\begin{array}{c}\text { Colocar na } \\
\text { pinga ou } \\
\text { no vinho } \\
\text { branco }\end{array}$ & Raiz \\
\hline Vick & Mentha arvensis L. & Lamiaceae & Mal de simioto & $\begin{array}{c}\text { Chá; } \\
\text { banho }\end{array}$ & Folha \\
\hline Vinagreira & Hibiscus sabdariffa & Malvaceae & Anemia & In natura & Folha \\
\hline
\end{tabular}

Tabela 1. Plantas medicinais e místico-religiosas utilizadas por benzedeiras e curandeiros no sul do estado de Mato Grosso. 2016

Fonte: Construção dos Autores

De acordo com os entrevistados, as pessoas procuram tratamento para os mais variados tipos de enfermidades (Figura 3), tanto o gênero feminino quanto o masculino, desde bebês até pessoas adultas e idosas. Para as crianças, buscam ajuda geralmente para quebrante e Mal de Simioto, já os adultos a procura é para erisipele, problemas emocionais e impotência sexual. Podemos constatar isso no relato a seguir: "... as pessoas buscam tratamento pra tudo... emocional, físico, psíquico... é a dor que bate de tudo que é forma... vem buscar um alívio para a dor..." (Sra. M.S.R.).

A forma de tratamento também é diversificada, conforme o problema mencionado pela pessoa. Assim, foram citadas: a) a benzeção - mistura de religiosidade e magia, é considerada uma forma de promover a cura de doenças em pessoas e animais ou ainda levar o bem-estar a um lugar, seguindo rituais específicos e praticada, geralmente, por pessoas mais velhas; $b$ ) a oração - prece ou reza dirigida a Deus ou a outro ser espiritual e integrada nos rituais de grande parte das religiões; c) o passe-usualmente transmitido pelas mãos, tem como finalidade auxiliar a recuperação de desarmonias físicas e psíquicas, transmitindo fluidos benéficos; d) os banhos - retiram as cargas negativas, protegem e curam contra doenças, mau-olhado, infortúnios e inveja, são preparados com ervas específicas; e) o chá - é a principal forma de preparo das plantas medicinais para o tratamento e a cura de diversas doenças (gripe, dor de cabeça, má digestão, emagrecer...), geralmente feito através de infusão, com a água fevente e as folhas ou outras partes da planta; ) a garrafada - é uma mistura de ervas, cascas, raízes e outros elementos naturais tradicionalmente usada para 
tratar doenças como inflamação, impotência sexual, problemas no sistema circulatório e fortalecer o útero e as trompas. Porém, para todas essas formas foi mencionada a importância da fé para obter o sucesso da cura.

As principais espécies de importância místico-religiosa são alecrim (Rosmarinus officinalis L.), alho (Allium sativum L), arruda (Ruta graveolens L.), comigo-ninguém-pode (Dieffenbachia amoena Bull.), espada-de-iansã (Sanseveria sp.), espada-de-ogum (Sanseveria sp.), espada-de-são-jorge (Sansevieria trifasciata Prain), guiné (Petiveria alliaceae L.), jurema (Pithecellobium tortum Mart.), pimenta (Capsicum albescens Kuntze), pinhão roxo (Jatropha gossypiifolia L.), rosa branca (Rosa alba L.). Essas plantas foram mencionadas, principalmente, como protetoras ou guardiãs, por esse motivo são cultivadas, preferencialmente, em frente a moradia. São utilizadas na benzeção e em banhos, ou ainda como amuleto em alguma peça de roupa para tirar o mau olhado, o quebrante, a inveja.

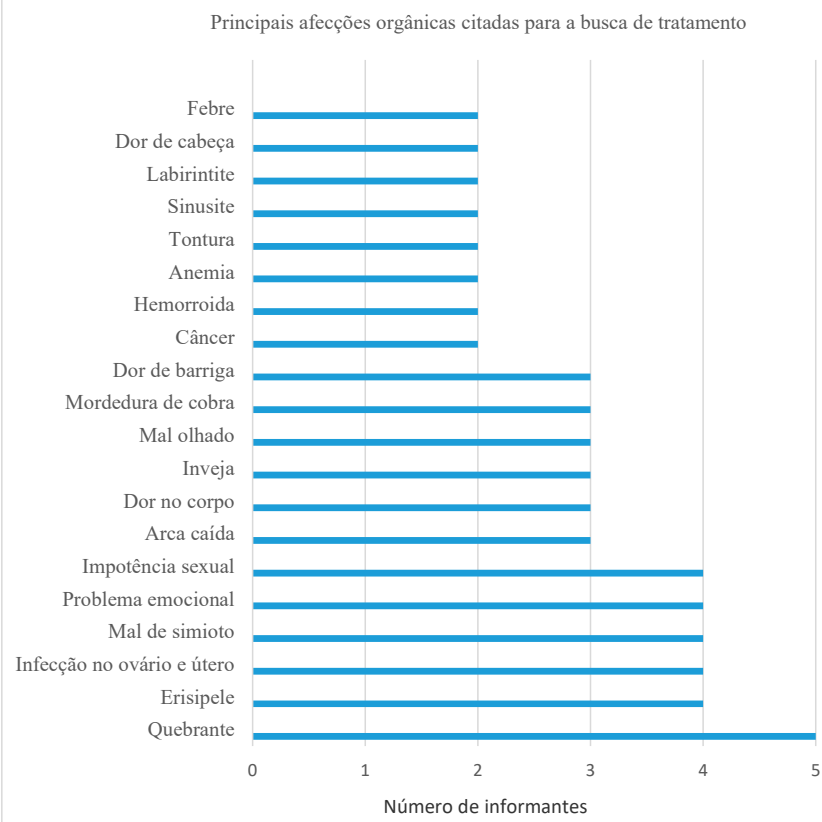

Figura 3. Afecções orgânicas tratadas por benzedeiras e curandeiros, MT. 2016 Fonte: Construção dos autores 
No nordeste brasileiro as plantas com funções protetoras são denominadas de "jurema", que segundo Mota e Albuquerque (2002):

“... Jurema é, portanto mais que uma planta, é representação, divindade que ocupam um papel destacado na flora nordestina pela referência mágico-religiosa... A Jurema penetrou na cultura popular estando associada à figura de índios, caboclos, negros e quilombolas, elementos presentes no imaginário popular..."

Quanto a espécie Mimosa hostilis (C.Mart.) Benth. (jurema) basinômio Acacia hostilis Mart. da família Fabaceae, largamente utilizada no Brasil, detectou-se relatos do seu uso para rituais místico-religiosos e para a proteção do corpo e da alma pelos depoentes do estudo realizado na Comunidade Quilombola Mata Cavalo de Baixo, em Nossa Senhora do Livramento, Mato Grosso.

Nesse estudo, as espécies místicas também revelam sua importância na vida das pessoas que moram na comunidade, como forma de proteção pessoal contra os males que acometem o corpo e a alma, através de banhos com uma só espécie ou com a junção de várias plantas e também através de benzimentos. Entre elas a Annona acutiflora Mart. (guiné), Rosmarinus officinalis L. (alecrim), Sansevieria trifasciata Prain (espada-de-São-Jorge), Ruta graveolens L. (arruda), Bryophyllum pinnatum (Lam.) Oken (fortuna), Vernonia ferruginea Less (assa-peixe), Dieffenbachia amoena Bull. (comigo-ninguém-pode) e Mimosa hostilis (C.Mart.) Benth (jurema). Os banhos protetores, como também ao corpo inteiro podem estar relacionados a uma parte do corpo ou banhos para curar a pessoa de algum mal que lhe acomete. $O$ simbolismo é expresso no conhecimento que a população detém sobre o uso popular de plantas com função protetora (PASA et al., 2015).

A Galeria de Imagens mostra as plantas utilizadas por benzedeiras e curandeiros em suas práticas de tratamento e cura.

\section{CONSIDERAÇÕES FINAIS}

No sul do estado de Mato Grosso, as plantas medicinais ocupam um lugar de destaque no cotidiano de benzedeiras e curandeiros, tanto para o preparo de chás, banhos e garrafadas, como 
para o benzimento e proteção. Dessa forma, estão presentes nos quintais das residências visitadas e, sobretudo nos rituais de benzimento e cura. Além das plantas, também são utilizados outros adereços como velas, cruz, imagens de santo, água, gestos e rezas.
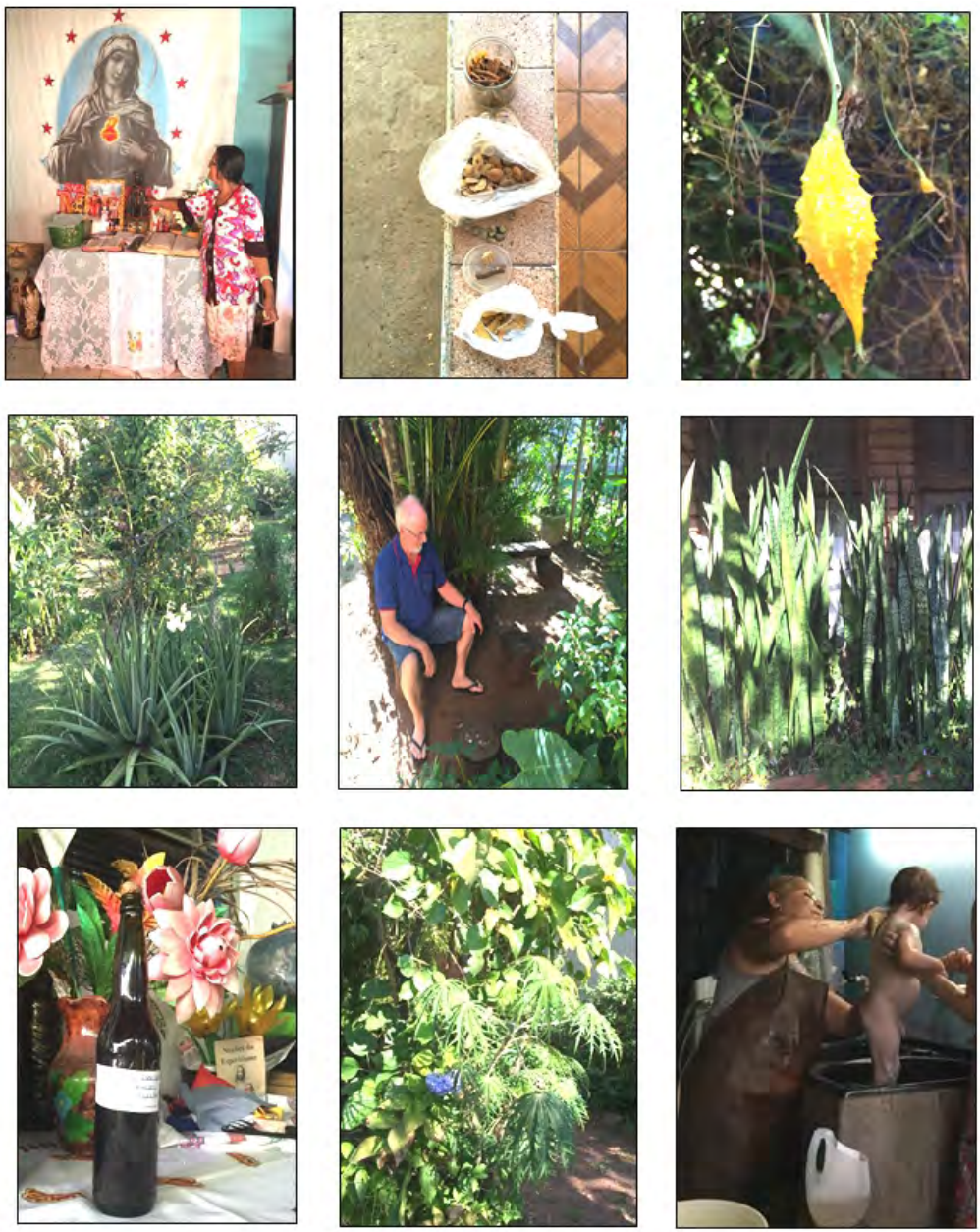

Galeria de imagens: 1- Benzedeira em seu nicho religioso; 2-Sementes e cascas de plantas medicinais; 3- Melão-de-são-caetano (Momordia charantia L.); 4-Babosa (Alloe vera (L.) Burm f.; 5- Informante em seu espaço sagrado; 6- Espécie 'guardiã', Espada de são jorge (Sanseveria trifasciata Praim); 7- Garrafada; 8-Cultivo de plantas no quintal; 9- Benzedeira realizando banho para tratar de mal de simioto. Fonte: Construção dos Autores 


\section{REFERÊNCIAS}

AMOROZO, M. C. M. A abordagem etnobotânica na pesquisa de plantas medicinais. In: DI STASI, L. C. (Ed.). Plantas medicinais: arte e ciência, um guia de estudo interdisciplinar. São Paulo: Editora UNESP, 1996. p. 47-68.

AMOROZO, M. C. M. Pluralistic medical settings and medicinal plants use in rural communities, Mato Grosso, Brazil. Journal of Ethnobiology, Denton, v. 24, n. 1, p. 139-161, 2004.

AMOROZO, M. C. M.; GELY, A. Uso de plantas medicinais por caboclos do Baixo Amazonas. Barcarena, PA, Brasil. Boletim Museu Paraense Emílio Goeldi, Série Botânica, Belém, v. 4, n. 1, p. 47-131, 1998.

BEGOSSI, A.; HANAZAKI, N.; TAMASHIRO, J. Y. Medicinal plants and the Atlantic Forest (Brazil): knowledge, use and conservation. Human Ecology, Ithaca, v. 30, n. 3, p. 281-299, 2002.

CABALLERO, J. La etnobotânica. In: BARRER, A. (Ed.). La etnobotânica: tres puntos de vista y uma perspectiva. Xalapa: Instituto de Investigación sobre Recursos Bióticos, 1979. p. 27-30.

CARVALHO, L. M. M. Estudos de Etnobotânica e Botânica Económica no Alentejo. 2006. 566 f. Tese (Doutoramento em Biologia - Sistemática e Morfologia) - Universidade de Coimbra, Coimbra. 2006.

CUNHA, L. A.; ASSUNÇÃO, L. C. Abençoada cura: poéticas da voz e saberes de benzedeiras. Revista Brasileira de História das Religiões, Maringá, v. 9, n. 27, p. 189-227, 2017.

CUTRIM, A. O.; CAMPOS, J. E. G. Avaliação da vulnerabilidade e perigo à contaminação do aquífero furnas na cidade de Rondonópolis (MT) com aplicação dos métodos God e Posh. Geociências, Diadema, v. 29, n. 3, p. 401-411, 2010.

FLORESTA, S. R. As benzedeiras do oeste goiano: resgatando uma história. In: CONGRESSO INTERNACIONAL DE HISTÓRIA: NOVAS EPÍSTEMES E NARRATIVAS CONTEMPORÂNEAS, 2016, Jataí. Anais... Jataí: UFG, 2016. Versão eletrônica.

GONÇALVES A. L.; ALVES-FILHO A.; MENEZES, H. Estudo comparativo da atividade antimicrobiana de extratos de algumas árvores nativas. Arquivos do Instituto Biológico de São Paulo, São Paulo, v. 72, n. 3, p. 353-358, 2005.

LORENZI, H.; MATOS, F. J. A. Plantas Medicinais no Brasil: nativas e exóticas. Nova Odessa: Instituto Plantarum, 2002. 512 p.

LOYOLA, M.A. Médicos e curandeiros: conflito social e saúde. São Paulo: Difel Ed., 1983.198p

LOZOYA X.; NAVARRO V.; ARNASON J. T.; KOURANY, E. Experimental evaluation of Mimosa tenuiflora (Willd.) Poir. (Tepeschohuite) I. screening of the antimicrobial properties of bark extracts. Archivos de Investigación Medica, Ciudad de México, v. 20, p. 87-93, 1989. 
MACIEL, M.; GUARIM NETO, G. Um olhar sobre as benzedeiras de Juruena (Mato Grosso, Brasil) e as plantas usadas para benzer e curar. Boletim Museu Paraense Emílio Goeldi, Ciências Humanas, Belém, v. 2, n. 3, p. 61-77, 2006.

MEIHY, J. C. S. B. Manual de História Oral. São Paulo: Loyola, 1996. 78 p.

MINAYO, M. C. S. Representações da cura no catolicismo popular. In: ALVES, P. C.; MINAYO, M. C. S. (Ed.). Saúde e doença: um olhar antropológico. Rio de Janeiro: Fiocruz, 1994. p. 57-71.

MING, L. C. Levantamento de plantas medicinais na Reserva Extrativista "Chico Mendes", Acre. 1995. 180 f. Tese (Doutorado em Botânica) - Universidade Estadual Paulista, Botucatu. 1995.

MIRANDA, T. M.; HANAZAKI, N. Conhecimento e uso de recursos vegetais de restinga por comunidades das ilhas do Cardoso (SP) e de Santa Catarina (SC), Brasil. Acta Botanica Brasilica, Feira de Santana, v. 22, n. 1, p. 203-215, 2008.

MOTA, C. N.; ALBUQUERQUE, U. P. (Org.). As muitas faces da Jurema: de espécie botânica à divindade afro-indígena. Recife: Bagaço. 2002. 192 p.

NOVAIS, A. M.; GUARIM NETO, G. Plantas medicinais em área florestal. In: GUARIM NETO, G.; CARVALHO, J. V. F. (Org.) Biodiversidade Mato-grossense: as plantas e suas potencialidades. Cuiaba: Carlini \& Caniato Editorial, 2011. p. 73-91.

OMS - ORGANIZAÇÃO MUNDIAL DE SAÚDE. Classificação estatística internacional de doenças e problemas relacionados à saúde. Vol. 1. São Paulo: EdUSP, 2000. $1191 \mathrm{p}$.

PASA, M. C. Um olhar etnobotânico sobre as comunidades do Bambá, Cuiabá, MT. Cuiabá: Ed. Entrelinhas, 2007. 143 p.

PASA, M. C.; DE DAVID, M.; DORVAL, A.; FIEBIG, G. A. A Etnobiologia na comunidade quilombola na Baixada Cuiabana, Mato Grosso, Brasil. In: PASA, M. C. (Org.). Múltiplos olhares sobre a biodiversidade IV. Cuiabá: Carlini \& Caniato Editorial, 2015. p. 341-368.

PORTUGUAL, F. Rezas, folhas, chás de Rituais dos Orixás: folhas, sementes, frutos e raízes de uso litúrgico na Umbanda e no Candomblé com uso prático na medicina popular. São Paulo: Ed. Tecnoprint, 1987. $153 \mathrm{p}$.

SANTOS, A. F.; CARVALHO, C. M.; COSTA, A. L. S.; CONCEIÇÃO, A. S.; MOURA, F. B. P.; SANTANA, A. E. G. Bioactivity Evaluation of plant extracts used in indigenous medicine against the snail, Biomphalaria glabrata, and the larvae of Aedes aegypti. Evidence-Based Complementary and Alternative Medicine, New York 2012. Article ID 846583, doi: 10.1155/2012/846583.

SANTOS, A. F.; LIMA, M. R. F.; OMENA, M. C. "A study of the larvicidal and molluscicidal activities of some medicinal plants from northeast Brazil." Journal of Ethnopharmacology, Shannon, v. 97, n. 2, p. 199-206, 2005.

WHO - WORLD HEALTH ORGANIZATION. Who handbook for reporting results for cancer treatment. Geneva: World Health Organization, 1979. 45 p. 